\title{
PENINGKATAN KEMAMPUAN MENGENAL BENTUK GEOMETRI MELALUI MAZE GEOMETRI PADA ANAK USIA 4-5 TAHUN
}

\author{
Safira $^{1}$, Fidesrinur $^{1}$ \\ Pendidikan Anak Usia Dini, Fakultas Psikologi dan Pendidikan, Universitas Al-Azhar \\ Indonesia, Komplek Masjid Agung Al-Azhar Jl. Sisingamangaraja, Jakarta Selatan, 12110 \\ E-mail : $\underline{\text { fideza@uai.ac.id }}$
}

\begin{abstract}
ABSTRAK- Perkembangan kognitif berhubungan erat dengan Matematika. Salah satu bagian dari pembelajaran Matematika adalah mengenal bentuk geometri. Salah satu media untuk mendukung pembelajaran Matematika dalam mengenal bentuk geometri yaitu dengan menggunakan media maze geometri. Penelitian ini bertujuan untuk meningkatkan kemampuan mengenal bentuk geometri melalui media maze geometri pada anak usia 4-5 tahun. Penelitian ini menggunakan metode Penelitian Tindakan Kelas. Pengumpulan data dilakukan dengan menggunakan observasi dan dokumentasi. Analisis data dilakukan dengan teknik data kualitatif dan kuantitatif. Penelitian ini dikatakan berhasil jika setiap indikator sudah mencapai target yang ditentukan yaitu $75 \%$. Hal tersebut dapat dilihat dari hasil penelitian yaitu rata-rata ketercapaian pada siklus I dalam mencocokkan $89.4 \%$, mengelompokkan sebesar 55\%, menyebutkan sebesar 52.2\%, dan menggambar bentuk geometri sebesar 33.2\% sedangkang rata-rata ketercapaian pada siklus II dalam mencocokkan sebesar 90.4\%, mengelompokkan sebesar $85.9 \%$, menyebutkan sebesar 90.5\%, dan menggambar bentuk geometri sebesar $77.5 \%$. Hasil penelitian menunjukkan bahwa media maze geometri dapat meningkatkan kemampuan mengenal bentuk geometri pada anak usia 4-5 tahun di BKB PAUD Melur.
\end{abstract}

Kata Kunci: Media, Maze, Geometri, Mengenal Bentuk, Kognitif

\begin{abstract}
Cognitive development is closely related to Mathematics. One part of learning Mathematics is recognizing geometric shapes. One of the media to support Mathematics learning in recognizing geometric shapes is by using media maze geometry. This study aims to improve the ability to recognize geometric shapes through geometric maze media in children aged 4-5 years. This study uses the Classroom Action Research method. Data collection is done using observation and documentation. Data analysis was carried out by qualitative and quantitative data techniques. This research is said to be successful if each indicator has reached the specified target of 75\%. This can be seen from the results of the study, namely the average achievement in the first cycle in matching $89.4 \%$, grouping by 55\%, mentioning $52.2 \%$, and drawing geometric shapes of $33.2 \%$ in the average achievement in cycle II matching at $90.4 \%$, classifying $85.9 \%$, mentioning $90.5 \%$, and drawing geometric shapes at $77.5 \%$. The results showed that geometry maze media can improve the ability to recognize geometric shapes in children aged 4-5 years in BKB Melur PAUD
\end{abstract}

Keywords: Media, Maze, Geometry, Know Shape, Cognitive 


\section{PENDAHULUAN}

P atar Belakang

erkembangan anak usia dini terdapat enam aspek yaitu aspek sosial-emosional, aspek fisik-motorik, aspek bahasa, aspek seni, aspek agama dan aspek kognitif, yang seluruhnya saling terkait dan berkembang secara bertahap sesuai dengan usia anak agar perkembangannya menjadi lebih optimal. Salah satu perkembangan yang perlu di stimulasi adalah aspek kognitif. Aspek kognitif penting untuk distimulasi karena sejak kecil anak mulai mengenal benda-benda disekitarnya. Anak mulai mengenal bola, buku, televisi, lemari dan benda lainnya yang bentuknya sama dengan bentuk geometri. Pengenalan bentuk geometri merupakan bagian dari pembelajaran Matematika. Pembelajaran Matematika terdiri dari tiga konsep pembelajaran diantaranya pembelajaran berhitung, geometri, dan pembelajaran pengukuran. Namun, pada umumnya anak merasa takut pada saat pembelajaran Matematika.

Hal ini diperkuat berdasarkan media online kompas female yang menjelaskan studi terbaru mengenai beberapa faktor anak memiliki ketakutan terhadap Matematika. Kecemasan terhadap Matematika ternyata dapat disebabkan oleh dua hal. Pertama, karena pengalaman negatif. Beberapa orang memiliki ketakutan terhadap berbagai jenis hitungan yang berhubungan dengan angka karena ia memiliki pengalaman negatif, misalnya menerima hukuman yang sangat berat karena ia kurang bisa dalam bidang Matematika. Kedua, adalah faktor genetika. Namun, faktor lain yang tidak kalah penting adalah lingkungan baik disekolah, dan dirumah. Pengamalan yang dialami seseorang bisa memberikan pengaruh terhadap kemampuannya dalam bidang Matematika. Oleh karena itu, guru berperan penting dalam memberikan pembelajaran Matematika yang sesuai dengan prinsip-prinsip pembelajaran anak usia dini.

Peraturan Menteri Pendidikan dan Kebudayaan RI No 137 Tahun 2014, terdapat prinsip-prinsip pembelajaran untuk pendidikan anak usia dini seperti belajar melalui bermain, berorientasi pada kebutuhan anak, berpusat pada anak, pembelajaran aktif, berorientasi pada pengembangan nilai-nilai karakter, berorientasi pada pengembangan kecakapan hidup, didukung dengan lingkungan kondusif, berorientasi pada pembelajaran yang demokratis, pemanfaatan media belajar, sumber belajar dan narasumber. Dengan adanya prinsip-prinsip tersebut, guru harus menciptakan pembelajaran yang aktif, inovatif, dan juga menyenangkan.

Salah satu contohnya, yang terjadi di BKB PAUD Melur pada tanggal 3 Agustus 2017, diperoleh informasi bahwa kemampuan anak pada pembelajaran Matematika di kelompok A (usia 4-5 tahun) yang berjumlah 14 anak masih rendah dalam mengenal bentuk geometri. Hal ini terlihat bahwa ketika ditanya anak tersebut masih kebingungan dalam menjawab bentuk yang diberikan. Data yang diperoleh melalui tes kemampuan mengenal bentuk geometri menggunakan media kartu geometri dalam kemampuan mengenal bentuk terdapat enam anak yang sudah mampu dalam mengenal bentuk dengan benar. Sedangkan terdapat delapan anak lainnya masih belum bisa menjawab dengan benar. Hasil wawancara dengan bu Yanti selaku kepala sekolah BKB PAUD Melur, menjelaskan bahwa kemampuan anak dalam mengenal bentuk geometri masih rendah dan membutuhkan adanya solusi.

Beberapa faktor yang menyebabkan rendahnya kemampuan anak dalam mengenal bentuk geometri yaitu minimnya media yang digunakan guru dalam mengajarkan bentuk geometri. Biasanya, Guru BKB PAUD Melur mengenalkan bentuk geometri menggunakan papan tulis, LKA, dan buku PR (Pekerjaan Rumah). Selain itu, media yang digunakan terlihat monoton sehingga tidak menjadi pusat perhatian anak. Faktor lain yang menyebabkan rendahnya kemampuan anak dalam mengenal bentuk geometri di BKB PAUD Melur yaitu guru lebih menekankan pembelajaran Calistung (Membaca, Menulis, dan Berhitung). Hal tersebut dikarenakan banyaknya tuntutan orangtua akan kemampuan calistung.

Meningkatkan kemampuan anak dalam mengenalkan bentuk geometri diperlukan media dan metode pembelajaran yang menarik bagi anak, salah satunya dilakukan dengan memperkenalkan media maze geometri. Media maze geometri merupakan istilah yang digunakan untuk media pembelajaran dalam penelitian ini. Maze pada umumnya adalah permainan untuk melatih strategi atau melatih mencari jalan keluar. Biasanya maze terbuat dari kertas atau karton yang di dalamnya berisi lajur-lajur sempit dengan berbagai perintah. 
Media maze geometri ini akan dilakukan dengan cara yang berbeda dari media maze yang sudah ada dengan cara memodifikasinya. Media maze geomteri ini dibuat dengan menggunakan bahan karpet busati, karton, duplek, ring basket dan kain flannel. Sedangkan selama ini anak hanya belajar dengan menggunakan papan tulis, LKA dan buku PR (perkerjaan rumah). Oleh karena itu, penulis memilih media maze geometri agar pembelajaran lebih menarik, menyenangkan dan anak lebih aktif dalam belajar. Selain itu, anak juga dapat memecahkan masalah dalam kehidupan sehari-harinya melaui media maze geometri.

\section{B. Identifikasi Masalah}

Dari latar belakang masalah yang telah diuraikan, maka identifikasi masalah dalam penelitian ini adalah sebagai berikut:

1. Media pembelajaran yang digunakan saat mengajar hanya menggunakan papan tulis, LKA, dan buku PR sehingga kemampuan mengenal geometri anak masih rendah.

2. Metode pembelajaran yang digunakan adalah ceramah, guru hanya bercerita di depan menerangkan gambar bentuk geometri, sehingga anak masih pasif dalam kegiatan pembelajaran.

3. Kegiatan pembelajaran dilakukan dengan mengerjakan dan mengulang-ulang LKA yang sama tanpa diselingi dengan kegiatan bermain, sehingga menyebabkan anak jenuh dengan kegiatan yang sama.

4. Pembelajaran geometri tidak dikaitkan langsung dengan benda - benda konkret, sehingga masih kurangnya pemahaman anak.

\section{Pembatasan Masalah}

Berdasarkan identifikasi masalah di atas, maka pembatasan masalah dalam penelitian ini difokuskan pada media maze geometri untuk meningkatkan kemampuan mengenal bentuk geometri pada anak usia $4-5$ tahun di BKB PAUD Melur. adapun Tujuan dari penelitian ini adalah untuk meningkatkan kemampuan mengenalkan bentuk geometri melalui media maze geometri pada anak usia $4-5$ di BKB PAUD Melur.

\section{Manfaat Penelitian}

Adapun manfaat dari penelitian ini adalah sebagai berikut:

1. Bagi Peneliti

Menambah ilmu pengetahuan dan meningkatkan kemampuan mengenalkan bentuk geometri melalui media maze geometri

2. Bagi Guru

a. Guru memperoleh wawasan dalam memilih dan menggunakan alternatif pembelajaran yang tepat dalam mengajar

b. Guru dapat menerapkan pembelajaran mengenalkan bentuk geometri dengan cara yang efektif dan menyenangkan dengan menggunakan media maze geometri.

c. Memudahkan guru dalam mengajarkan bentuk geometri.

d. Membangkitkan kreatifitas guru dalam menerapkan dan menciptakan inovasi dalam kegiatan pembelajaran.

3. Bagi Kepala Sekolah

Memberikan masukan kepada kepala sekolah dalam mengambil kebijakan dalam meningkatkan kemampuan mengenal bentuk geometri melalui media maze geometri.

\section{KERANGKA TEORI}

\section{A. Perkembangan Kognitif Anak Usia Dini} (4-5 Tahun)

1. Kemampuan Anak Mengenal Geometri

Jamaris, (dalam Charlesworth, 1990) menjelaskan bahwa anak mulai mengenal atau mengetahui ada bentuk-bentuk dasar (bentuk geometri) yang mempunyai namanama sendiri. Pada saat pembelajaran awal biasanya anak belajar nama setiap bentuk tersebut, seperti lingkaran, persegi, dan segitiga. Baru kemudian mereka belajar persegi panjang, belah ketupat, dan bentuk lainnya.

Berdasarkan teori di atas, dapat disimpulkan bahwa anak usia 4-5 tahun sudah mampu mengenal bentuk geometri. Bentuk dasar geometri yang anak kenal terlebih dahulu ialah segi tiga, segi empat, dan lingkaran. Setelah mempelajari geometri dasar, anak baru memulai mengenal bentuk yang lain seperti persegi panjang, dan sebagainya. 
2. Tahap Mengenal Geometri

Menurut Bloom (dalam Anderson, 2010: 100), seorang anak dikatakan paham apabila melewati proses kognitif, yaitu: menafsirkan (interpreting), mencontohkan (exemplifying), klasifikasi (classifying), merangkum (summarizing), menyimpulkan (inferring), membandingkan (comparing), dan menjelaskan (explaining). Berdasarkan penjelasan tersebut, dapat disimpulkan bahwa pemahaman yang sempurna ditunjukan dengan tujuh kemampuan yang ada.

Sedangkan menurut Stanford dan Zelma (dalam Smith, 2009), anak-anak mengeksplorasi bentuk dengan berbagai cara. Terdapat empat tingkat kesulitan dalam proses mengenal bentuk, yaitu (a) Tingkat 1: mencocokkan satu bentuk dengan bentuk yang sama seperti "Letakkan segitiga pada gambar segitiga.", (b) Tingkat 2: urutkan bentuk dengan persamaan seperti "Letakkan semua segitiga di satu tumpukan dan semua lingkaran di lingkaran lain", (c) Tingkat 3: memberi nama bentuknya. "Bentuk apa ini", (d) Tingkat 4: menggambar bentuk. Salin dari model atau gambar dari memori (sulit).

Adapun tahapan yang peneliti gunakan adalah menurut Stanford dan Zelman, yaitu dengan mencocokkan bentuk, mengklasifikasi, menyebutkan nama bentuk, dan menggambarkan bentuk geometri. Alasan peneliti memilih tahapan ini karena lebih sesuai dengan keadaan di lapangan.

\section{B. Media Maze Geometri}

1. Pengertian Media Pembelajaran

Media pembelajaran menurut Gagne, Rossi dan Breidle (1966) adalah seluruh alat dan bahan yang dapat dipakai untuk tujuan pendidikan, seperti televisi, buku, koran, majalah, dan sebagainya. Menurut Rossi, alat-alat semacam radio dan televisi kalau digunakan dan diprogram untuk pendidikan, maka merupakan media pembelajaran. Sejalan dengan itu, menurut Gagne dan Briggs (dalam Hasnida, 2014), secara implisit mengatakan bahwa media pembelajaran meliputi alat yang secara fisik digunakan untuk menyampaikan isi materi pengajaran yang terdiri dari buku, tape recorder, kaset, video camera, video recorder, film, slide (gambar bingkai), foto, gambar, grafik, televisi, dan komputer. Dengan kata lain, media adalah komponen sumber belajar atau wahana fisik yang mengandung materi instruksional di lingkungan siswa yang dapat merangsang siswa untuk belajar.

\section{Pengertian Maze Geometri}

Maze (dalam Rosidah, 2014) adalah sebuah permainan dengan jalan sempit yang berliku dan kadang kala merupakan jalan buntu ataupun jalan yang mempunyai halangan. Hal senada (dalam Rosidah, 2014) menjelaskan bahwa permainan maze adalah permainan sejenis puzzle berbentuk lajur-lajur yang bercabang dan berliku-liku.

Berdasarkan uraian di atas dapat disimpulkan bahwa, maze adalah permainan yang mencari jalan keluar yang memiliki jalan bercabang, dan berliku-liku untuk melatih konsentrasi, koordinasi tangan dan mata, dan melatih motorik halus. Dengan permainan maze secara langsung maupun tidak langsung guru sudah mengedukasi anak agar berkonsentrasi, berkoordikasi, serta melatih motorik halus anak.

Maze geometri merupakan istilah yang digunakan untuk media pembelajaran yang digunakan dalam penelitian ini. Media maze geometri dapat digunakan untuk pembelajaran di Taman Kanak-kanak sebagai media pembelajaran untuk mengenal bentuk-bentuk geometri seperti segi tiga, segi empat, dan lingkaran. Media maze geometri ini dirancang agar anak mampu mengenal bentuk geometri dengan lebih efektif dan menyenangkan.

\section{METODE PENELITIAN}

\section{A. Jenis Penelitian}

Menurut Kemmis dan Mc. Taggart (dalam Muslich, 2009: 8), penelitian tindakan kelas adalah studi yang dilakukan untuk memperbaiki diri sendiri, pengalaman kerja sendiri, yang dilaksanakan secara sistematis, terencana, dan dengan sikap mawas diri.

\section{B. Lokasi Penelitian}

1. Tempat Penelitian

Penelitian Tindakan Kelas ini dilaksanakan di BKB PAUD Melur, jl. BDN II, Cilandak Barat, Jakarta Selatan. 
Alasan penulis memilih BKB PAUD Melur sebagai tempat penelitian karena penulis melihat terdapat suatu masalah yang terjadi di dalam kelas yaitu masih rendahnya kemampuan anak usia 4-5 tahun dalam mengenal bentuk geometri, selain itu media maze geometri dan belum pernah diterapkan dalam pembelajaran geometri khususnya untuk mengenalkan bentuk bentuk geometri kepada anak.

2. Waktu Penelitian

Penelitian yang dilakukan dengan metode Penelitian Tindakan Kelas ini dilaksanakan pada bulan OktoberNovember Tahun Ajaran 2017 - 2018. Penelitian ini dilakukan selama dua siklus di mana setiap siklus terdapat beberapa kali pertemuan.

\section{Subjek Penelitian}

Subjek dalam penelitian ini adalah anak Kelompok A yang berusia $4-5$ tahun di BKB PAUD Melur Tahun Ajaran 2017 - 2018 berjumlah 14 anak yang terdiri dari 8 anak perempuan dan 6 anak laki-laki.

\section{Desain Penelitian}

Penelitian tindakan kelas dilakukan melalui empat tahap yaitu perencanaan tindakan, observasi, dan refleksi. Secara keseluruhan, empat tahapan dalam penelitian tindakan kelas membentuk suatu putaran yang disebut dengan siklus. Namun untuk menyelesaikan suatu permasalahan diperlukan lebih dari satu siklus. Pada siklus kedua penelitian akan disesuaikan dengan kebutuhan sampai dapat mencapai target yang diinginkan.

Proses penelitian tindakan kelas dapat digambarkan sebagai berikut:

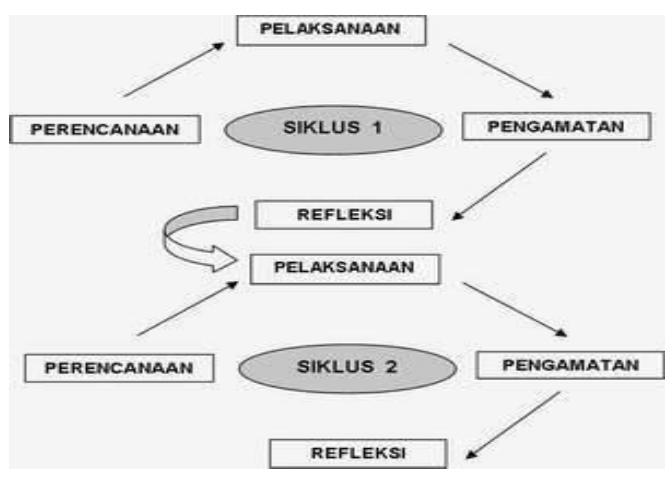

Gambar 1. Skema Kemmis \& Mc. Taggart

\section{E. Prosedur Penelitian}

Berdasarkan desain penelitian di atas, maka prosedur atau langkah-langkah dalam penelitian ini diuraikan sebagai berikut:

1. Tahapan Perencanaan (Planning)

2. Tahapan Pelaksanaan Tindakan

3. Tahapan Observasi

4. Tahapan Refleksi (Reflection)

\section{F. Teknik Pengumpulan Data}

Teknik pengumpulan data merupakan cara peneliti untuk memperoleh data. Adapun teknik yang digunakan dengan cara Observasi/ pengamatan serta dokumentasi/ foto

\section{G. Instrumen Penelitian}

Instrumen yang digunakan dalam penelitian ini adalah lembar observasi tentang peningkatan kemampuan mengenal bentuk geometri pada anak usia 4 - 5 tahun dengan menggunakan media maze geometri, lembar observasi aktivitas anak dalam proses pembelajaran, dan juga lembar observasi aktivitas guru dalam memberikan kegiatan pembelajaran.

\section{H. Teknik Analisis Data}

Data yang dikumpulkan pada setiap kegiatan observasi dari pelaksanaan siklus penelitian dianalisis menggunakan teknik data kualitatif dan kuantitatif. Teknik data kualitatif untuk menggambarkan kondisi atau suasana pembelajaran secara langsung baik guru maupun anak dan teknik kuantitatif untuk mengukur skor/ presentase keberhasilan kemampuan anak dalam mengenal bentuk geometri menggunakan media maze geometri. Dengan demikian dapat diketahui sejauh mana upaya dalam meningkatkan kemampuan anak mengenal bentuk geometri yang telah dicapai setelah menggunakan media maze geometri.

\section{Indikator Keberhasilan Penelitian}

Indikator keberhasilan dalam penelitian ini adalah anak diharapkan mampu menyebutkan bentuk geometri setelah melakukan pembelajaran tentang geometri melalui media maze geometri. Penelitian ini dikatakan berhasil apabila $75 \%$ dari 14 anak mampu mencapai skor tiga pada setiap butir indikator (dalam Tampubulon, 2014: 35). Rumus yang digunakan sebagai berikut (dalam Sudjono, 2004: 146) 


$$
\mathrm{P}=\frac{\mathrm{F}}{\mathrm{N}} \times 100 \%
$$

Keterangan:

$\mathrm{P}=$ Angka Presentasi

$\mathrm{F}=$ Frekuensi aktivitas anak

$\mathrm{N}=$ Jumlah anak dalam satu kelas

\section{HASIL DAN PEMBAHASAN}

A. Hasil Penelitian

1. Temuan Umum

BKB PAUD Melur terletak dijalan BDN II RT.02 RW.011 Cilandak Barat, Jakarta Selatan. BKB PAUD didirikan pada 9 September 2009, dan diresmikan oleh Lurah Cilandak Barat pada 11 Januari 2010. Lahan yang digunakan adalah milik Pemerintah Daerah DKI Jakarta seluas 100 $\mathrm{M}^{2}$ yang dibangun dari swadaya masyarakat dan bantuan fisik yang bergulir dari PPMK RW. 011 Cilandak Barat.

2. Temuan Khusus

Penelitian Tindakan Kelas (PTK) ini dilaksanakan menjadi dua siklus, di mana siklus satu terdiri dari lima kali pertemuan dan siklus dua terdiri dari empat kali pertemuan. Indikator yang akan dinilai pada penelitian ini adalah kemampuan anak dalam mencocokan bentuk geometri, mengelompokkan bentuk geometri, menyebutkan bentuk geometri, dan menggambar bentuk geometri melalui media maze geometri.

a. Siklus I

1) Perencanaan

Tahap perencanaan, peneliti membuat persiapan pembelajaran yang akan dilakukan pada siklus I. Peneliti mendiskusikan tema pembelajaran dan mempersiapkan Rencana Pelaksanaan Pembelajaran Harian (RPPH) bersama dengan guru kelas. Kemudian, peneliti mempersiapkan media pembelajaran yang akan digunakan dalam mengenalkan bentuk geometri, menyiapkan lembar observasi kemampuan mengenal bentuk geometri, lembar observasi aktivitas guru dan anak.
2) Pelaksanaan Tindakan

Melaksanakan tindakan sesuai dengan apa yang telah direncanakan.

3) Observasi

a) Hasil pengamatan kemampuan anak dalam mengenal bentuk geometri siklus I diuraikan melalui diagram berikut ini:

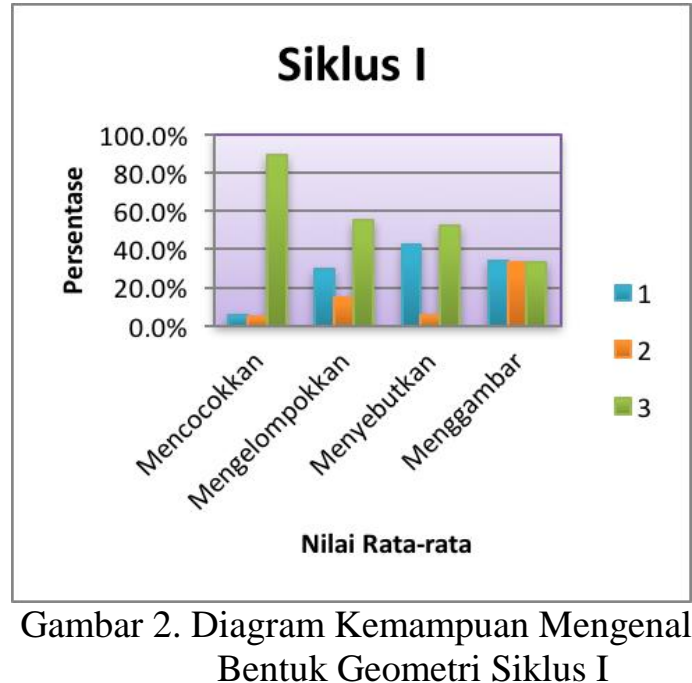

b) Hasil pengamatan aktivitas guru dan anak pada saat proses pembelajaran disiklus I diuraikan melalui diagram dan tabel berikut ini:

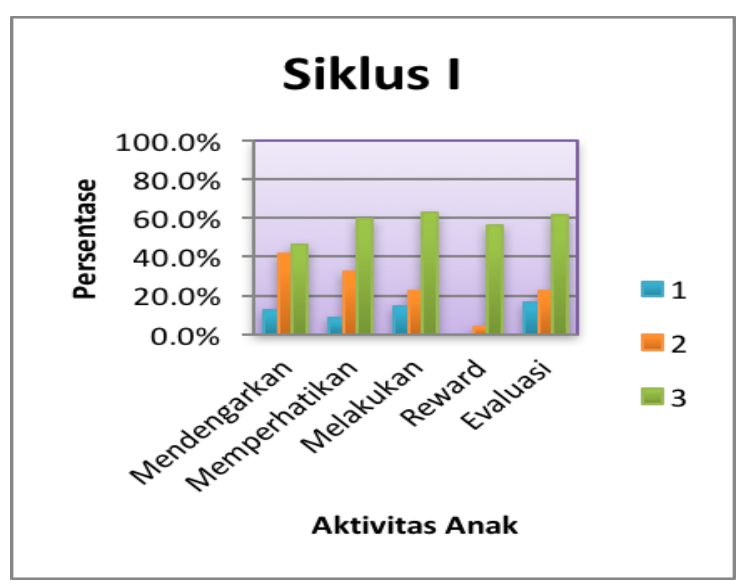

Gambar 3. Diagram Observasi Aktivitas Anak pada Siklus I

4) Refleksi Tindakan Siklus I

Hasil pengamatan penelitian pada siklus I menunjukkan bahwa indikator keberhasilan belum tercapai. 
Berdasarkan hasil pengamatan dan diskusi oleh peneliti, guru dan teman sejawat, diperoleh hal-hal yang menjadi penghambat pada siklus I, antara lain:

a) Guru dinilai terlalu cepat dalam menjelaskan kegiatan

b) Guru belum memberikan reward setiap harinya

c) Guru kurang menjelaskan tujuan dari diberikannya reward kepada anak.

d) Guru masih membiarkan anak yang diluar kelas pada saat kegiatan evaluasi.

e) Guru memberikan LKA yang terlalu mudah sehingga anak yang sudah selesai mengganggu teman lainnya.

f) Media mencocokkan membuat guru membuthkan waktu dalam mengeluarkan kartu

g) Anak masih berjalan pada karpet maze tanpa mengikuti jalan yang sesuai.

h) Anak masih kesulitan untuk menggambar bentuk geometri tanpa contoh.

b. Siklus II

1) Perencanaan

a) Guru disarankan untuk menjelaskan kegiatan secara pelan dan jelas.

b) Guru disarankan memberikan reward yang bervariatif setiap hari kepada anak.

c) Guru diminta menjelaskan tujuan memberikan reward kepada anak.

d) Guru disarankan memperhatikan seluruh anak sebelum memulai kegiatan pembelajaran.

e) Guru memberikan LKA yang tidak terlalu mudah.

f) Guru memodifikasi media mencocokkan sehingga lebih efisien dan efektif.

g) Guru memberikan instruksi dengan jelas sehingga anak dapat berjalan pada jalan yang sesuai karpet maze.

h) Guru memberikan LKA sehingga anak dapat menggambar dengan contoh yang ada.
2) Pelaksanaan Tindakan

Melaksanakan tindakan sesuai dengan apa yang telah direncanakan.

3) Observasi

a) Hasil pengamatan kemampuan anak dalam mengenal bentuk geometri pada siklus II diuraikan melalui diagram berikut ini:

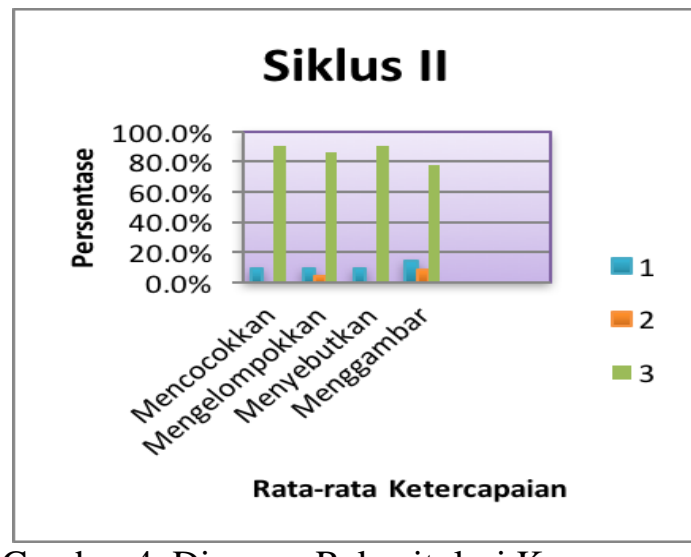

Gambar 4. Diagram Rekapitulasi Kemampuan Mengenal Bentuk Geometri pada Siklus II

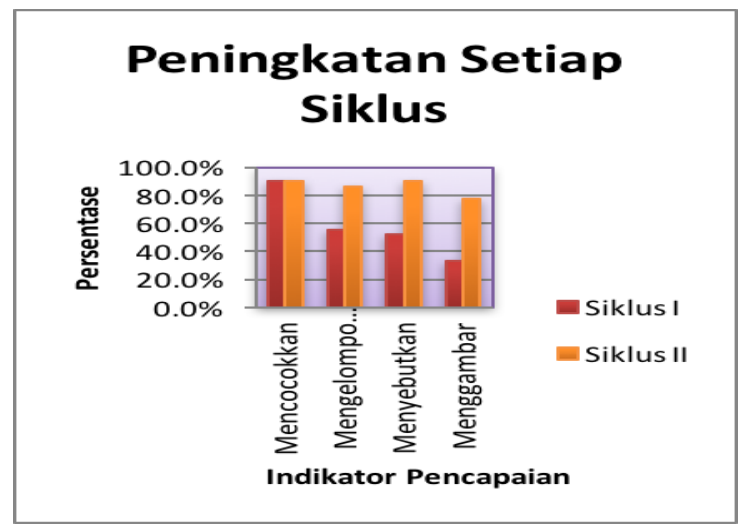

Gambar 5. Diagram Presentase Peningkatan Setiap Siklus

b) Hasil pengamatan aktivitas guru dan anak saat proses pembelajaran di siklus II diuraikan melalui diagram dan tabel berikut ini: 


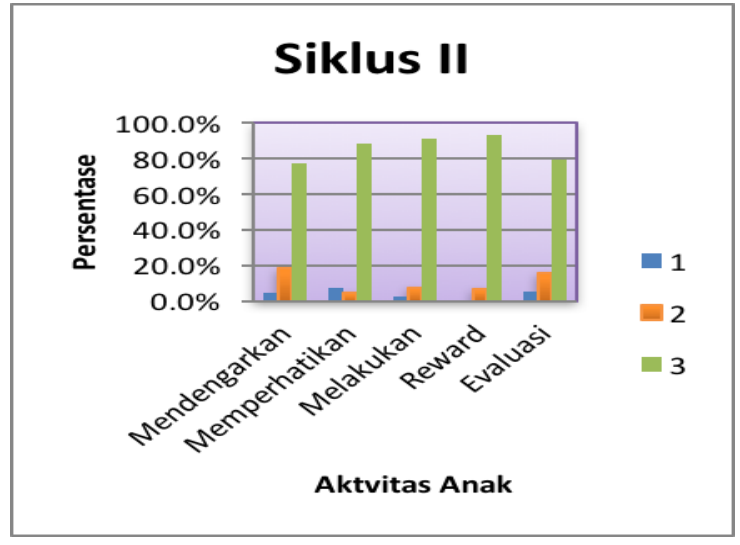

Gambar 6. Diagram Nilai rata-rata Aktivitas Anak Siklus II

Tabel 1. Rekapitulasi Observasi Aktivitas Guru pada Siklus II

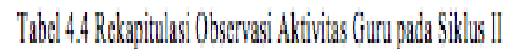

\begin{tabular}{|c|c|c|c|c|c|c|c|c|c|c|}
\hline \multirow[t]{2}{*}{ "Sllus } & \multicolumn{2}{|c|}{ 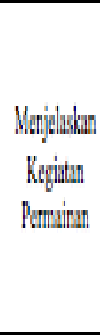 } & \multicolumn{2}{|c|}{ 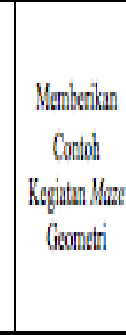 } & \multicolumn{2}{|c|}{ 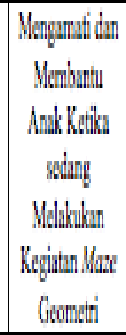 } & \multicolumn{2}{|c|}{ 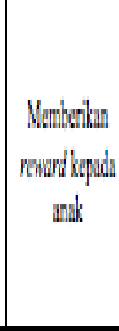 } & \multicolumn{2}{|c|}{$\begin{array}{l}\text { Melduban } \\
\text { wahisi }\end{array}$} \\
\hline & 16 & is & $a b$ & is & 106 & is & $\begin{array}{lll}a & b \\
\end{array}$ & b & & is \\
\hline Pent & & 1 & & 1 & & 1 & & 1 & 1 & \\
\hline Pert? & & 1 & & 1 & & 1 & & 1 & & 1 \\
\hline Pent? & & 1 & & 1 & & 1 & & & & 1 \\
\hline Pent 4 & & 1 & & 1 & & 1 & & 1 & & 1 \\
\hline
\end{tabular}

4) Refleksi

Berdasarkan hasil observasi dan refleksi siklus II, didapatkan hasil bahwa terdapat peningkatan pada kemampuan mengenal bentuk geometri, aktivitas anak dan guru. Tindakan pada siklus II telah mencapai indikator keberhasilan penelitian, sehingga peneliti menghentikan penelitian ini pada siklus II karena sudah mencapai indikator keberhasilan yang telah ditetapkan.

\section{B. Pembahasan}

Berdasarkan data yang diperoleh pada siklus II, dapat dikatakan bahwa tindakan yang dilakukan telah berhasil karena nilai yang diperoleh anak sudah melebihi target yang telah ditentukan pada indikator keberhasilan yaitu sebesar $75 \%$. Ketercapaian ini diperoleh karena dalam mengenalkan bentuk geometri dilakukan dengan kegiatan maze geometri. Melalui kegiatan maze geometri dapat mempermudah anak dalam mengenal bentuk geometri baik dalam mencocokkan, mengelompokkan, menyebutkan, dan menggambar bentuk.

Berdasarkan Peraturan Menteri Pendidikan dan Kebudayaan RI Nomor 137 Tahun 2014 Tentang Standar Pendidikan Anak Usia Dini dalam Standar Pencapaian Perkembangan Anak, kemampuan anak pada usia 4-5 tahun berada dalam kemampuan berpikir logis, yaitu pencapaian anak sudah mampu mengklasifikasikan benda berdasarkan fungsi, bentuk, atau warna atau ukuran. Untuk mencapai keberhasilan indikator tersebut, pada siklus I menggunakan media maze geometri, buku pengenalan bentuk, kertas ukuran A5, kotak geometri dan kartu gambar. Pada siklus II, peneliti tetap menggunakan media yang sama dengan siklus I, namun peneliti mengubah kegiatan mencocokkan dengan kalender geometri dan menggabungkan kegiatan mengelompokkan dan kegiatan menyebutkan menjadi satu.

Adapun peningkatan hasil pada siklus I, rata-rata ketercapaian dalam mencocokkan bentuk geometri yaitu sebesar $89.4 \%$, mengelompokkan bentuk geometri sebesar $55 \%$, menyebutkan bentuk geometri sebesar $52.2 \%$, dan menggambar bentuk geometri sebesar $33.2 \%$. Dari siklus I dan II, masingmasing anak pada tiap indikator menunjukkan adanya keberhasilan $75 \%$.

Melalui kegiatan maze geometri anak terlibat langsung dalam proses pembelajaran dan menggunakan media lain yang membuat anak semangat karena pada proses pembelajaran sebelumnya hanya mengajarkan bentuk geometri melalui papan tulis atau lembar kerja anak (LKA). Faktor lain yang mendukung meningkatnya kemampuan anak dalam mengenal bentuk geometri adalah dengan adanya reward yang diberikan guru. Adanya reward membuat anak lebih semangat dan senang dalam mengikuti setiap kegiatan pada maze geometri.

Kegiatan maze geometri ini bukan hanya menstimulasi $\mathrm{p}$ aspek perkembangan kognitif saja, akan tetapi mencakup aspek perkembangan lainnya, seperti agama dan moral, fisik-motorik, sosio emosional, bahasa, dan seni. Untuk aspek perkembangan agama dan moral, anak dapat menaati aturan, sopan 
dan dan hormat kepada guru. Pada perkembangan fisik motorik, anak mampu berjalan dan meletakkan kartu pada tiang geometri. Pada aspek perkembangan bahasa, anak dapat memahami peraturan dan perintah yang telah ditentukan guru. Kemudian, untuk aspek perkembangan seni, anak dapat mewarnai gambar pada kegiatan menggambar. Oleh sebab itu, kegiatan maze ini merupakan kegiatan yang teritegrasi dengan aspek perkembangan anak lainnya.

\section{SIMPULAN DAN SARAN}

\section{A. Simpulan}

Berdasarkan hasil penelitian dan pembahasan yang telah diuraikan, dapat disimpulkan bahwa terdapat peningkatan dalam kemampuan mengenal bentuk geometri pada anak usia 4-5 tahun di BKB PAUD Melur. Terjadinya peningkatan tersebut dikarenakan dalam mengenalkan bentuk geometri dilakukan dengan media maze geometri yang sebelumnya belum pernah diterapkan dalam mengenalkan bentuk geometri kepada anak. Selain itu, dalam merencanakan penggunaan media maze geometri mengacu pada PERMENDIKBUD Nomor 137 tahun 2014 Tentang Standar Pendidikan Anak Usia Dini dalam Standar Pencapaian Perkembangan Anak, kemampuan kognif anak pada usia 4-5 tahun berada dalam Kompetensi Dasar 3.6 dimana anak mampu mengenal benda-benda di sekitarnya seperti nama, warna, bentuk, ukuran, pola, sifat, suara, tekstur, fungsi, dan ciri-ciri lainnya. Selain itu, faktor yang mendukung meningkatnya kemampuan anak dalam mengenal bentuk geometri adalah dengan adanya reward yang diberikan guru, yang membuat anak lebih semangat dan senang dalam mengikuti setiap kegiatan dengan maze geometri.

\section{B. Saran}

Adapun saran yang dapat diberikan adalah:

1. Bagi Guru

a. Sebaiknya guru memberikan LKA yang tidak terlalu mudah pada saat kegiatan sehingga anak yang sudah selesai tidak mengganggu teman.

b. Sebaiknya guru meningkatkan kembali penguasaan kelas, sehingga pembelajaran dapat berlangsung tertib dan efektif. c. Sebaiknya guru lebih variatif dalam memberikan reward.

2. Bagi Kepala Sekolah

Kepala sekolah sebaiknya memanfaatkan media yang ada serta memvariasikan kegiatan pembelajaran agar lebih bermakna.

\section{DAFTAR PUSTAKA}

Anderson, O.W., Krathwohl, D.R. (2010). Kerangka landasan untuk pembelajaran, pengajaran, dan asesmen. Yogyakarta: Pustaka Pelajar.

Charlesworth, R. (1990). Math and science for young children. Newyork: Delmar Publisher Inc.

Muslich, M. (2009). Melaksanakan PTK itu mudah (Classroom Action Research). Jakarta: PT Bumi Aksara.

Peraturan Kementerian Pendidikan dan Kebudayaan Republik Indonesia No. 137 Tahun 2014.

Rosidah, L. (2014). Peningkatan kecerdasan visual spasial anak usia dini melalui permainan maze. e-Journal PG PAUD Universitas Ageng Tirtayasa Banten Jurusan Pendidikan Guru Pendidikan Anak Usia Dini. Volume 8. No 2. Diakses pada http://pps.unj.ac.id/journal/jpud/article/view 178/78.

Tampubulon, S. (2014). Penelitian tindakan kelas. Jakarta: Erlangga. 